\title{
Reduced expression of peroxisome proliferator-activated receptor alpha in BAL and blood T cells of non-löfgren's sarcoidosis patients
}

\author{
Muntasir Abo Al Hayja ${ }^{1,2^{*}}$, Anders Eklund', Johan Grunewald ${ }^{1}$ and Jan Wahlström ${ }^{1}$
}

\begin{abstract}
Background: Sarcoidosis is a granulomatous disease affecting in particular the lungs. The peroxisome proliferator-activated receptors (PPARs) play important regulatory roles in inflammation. The aim of this study was to gain more insight about the expression of all three PPARs $(\alpha, \beta / \delta$ and $\gamma)$ in sarcoidosis.

Methods: Bronchoalveolar lavage (BAL) cells and peripheral blood cells were obtained from healthy controls (HC) and sarcoidosis patients with Löfgren's syndrome (LS) and without Löfgren's syndrome (non-LS). PPARs mRNA expression was analyzed in total BAL cells and in FACS (Fluorescence-activated cell sorting) sorted alveolar macrophages (AM) and $C D 4^{+} T$ cells respectively by comparative RT-PCR. PPARs protein expression was analyzed in $\mathrm{AM}$, and in $\mathrm{BAL}$ and blood $\mathrm{CD} 4^{+}$and $\mathrm{CD} 8^{+} \mathrm{T}$ cells by flow cytometry.

Results: In BAL CD4 ${ }^{+}$T cells, we noticed a significantly lower PPARa mRNA expression in sarcoidosis patients compared with HC. In non-LS patients, a significantly lower PPARa protein expression in BAL CD4 ${ }^{+} \mathrm{T}$ cells was detected as compared with LS patients. In peripheral blood CD4 ${ }^{+} T$ cells, non-LS patients had a significantly lower expression of PPARa and PPARY compared with LS patients.
\end{abstract}

Conclusion: The lower protein expression of PPARa and PPARy could contribute to the persistent T-cell driven inflammation noted especially in non-resolving sarcoidosis, common in non-LS patients.

Keywords: Peroxisome proliferator-activated receptors $\alpha, \beta / \delta$ and $\gamma$, Sarcoidosis, Bronchoalveolar lavage (BAL), Flow cytometry, BAL and blood CD4 ${ }^{+}$- and $C D 8^{+}$T lymphocytes, Alveolar macrophages, RT-PCR

\section{Introduction}

Sarcoidosis is a systemic disease characterized by noncaseating granulomas affecting many organs, in particular the lungs and the intrathoracic lymph nodes [1]. Sarcoidosis is a multifactorial [2] disease, where environmental factors and several genetic loci contribute to the pathogenesis of the disease [3]. Moreover, some studies have suggested that sarcoidosis is associated with increased risk of cancer $[4,5]$. The cause of sarcoidosis remains elusive. Evidence points towards that sarcoidosis is an exaggerated immune response to persistent antigens from not completely degraded bacteria such as mycobacteria and propionibacterium acnes [1].

\footnotetext{
* Correspondence: muntasir.abo.al.hayja@ki.se

'Department of Medicine and CMM, Respiratory Medicine Unit, Karolinska Institutet and Karolinska University Hospital Solna, Stockholm, Sweden

${ }^{2}$ Lung Research Laboratory L4:01, Karolinska University Hospital Solna, S-171 76 Stockholm, Sweden
}

In sarcoidosis, the interaction between antigen presenting cells (APCs) and an unknown antigen(s) leads to a polarized T-helper 1 (Th1) $\mathrm{CD}_{4}^{+}$response including production of Th1 cytokines such as interferon-gamma (IFN- $\gamma$ ), tumor necrosis factor- $\alpha$ (TNF- $\alpha$ ) and interleukin-2 (IL-2) [1], and the formation of granulomas. Pulmonary sarcoidosis is characterized by an increased number of $\mathrm{CD}^{+} \mathrm{T}$ cells in bronchoalveolar lavage fluid (BALF). Analyses of the T Cell Receptor (TCR) suggest oligoclonal expansion of the $\mathrm{CD} 4^{+}$ $\mathrm{T}$ cells using particular $\mathrm{V} \alpha$ or $\mathrm{V} \beta$ genes [3]. In most cases the granulomas resolve, but in some cases the local environment of the granulomas may change to promote the development of fibrosis [1].

The clinical presentation of sarcoidosis ranges from an incidental chest radiographic finding in an asymptomatic patient to chronic progressive organ dysfunction. A distinct subgroup of sarcoidosis patients is Löfgren's syndrome 
(LS), characterized by an acute onset with bilateral hilar lymphadenopathy and in some cases parenchymal infiltrates, erythema nodosum and/or bilateral ankle arthritis or periarticular inflammation, and usually fever [3]. Patients with LS often have spontaneously resolving disease, while patients without LS (non-LS) often present with a more gradual, insidious onset, and are more likely to develop chronic disease. Studies from our laboratory of Swedish patients with sarcoidosis demonstrated a strong correlation between the carriage of HLA-DRB1*0301 $\left(\mathrm{DR}^{+}\right)$and the development of LS and with disease resolution [3].

The peroxisome proliferator-activated receptors (PPARs) play important regulatory roles in numerous cellular processes related to metabolism, differentiation, proliferation, and inflammation. PPARs are a subgroup of the nuclear receptor (NR) superfamily. Three PPARs have been described, which are designated as $\alpha, \beta / \delta$ and $\gamma$ forms. The PPARs are expressed in many cell types, including macrophages and T lymphocytes [6,7]. All three PPARs subtypes can be activated by a variety of polyunsaturated long-chain fatty acids, prostaglandins, leukotrienes, and by many synthetic compounds [8]. PPAR $\alpha$ is specifically activated by fibrates (used to treat hypertriglyceridemia and hyperlipidemia), whereas PPAR $\gamma$ is activated by glitazones (used to treat diabetes type II). PPARs regulate gene expression after binding as a heterodimer with the retinoid X receptors (RXRs) and accumulation in the nucleus. A major role for PPARs is the trans-suppression of inflammatory gene activation by interfering with the NF- $\mathrm{BB}$, STAT-1, and AP-1 transcription complexes without direct binding to the DNA [9]. PPAR $\alpha$ PAR $\beta / \delta$ and PPAR $\gamma$ ligands have been reported to inhibit Th1 pro-inflammatory cytokine production by activated $\mathrm{T}$ cells $[10,11]$.

PPAR $\alpha$ and PPAR $\gamma$ are recognized as potentially important players in immunomodulation and anti-inflammatory regulation in different inflammatory disorders including pulmonary diseases such as COPD and asthma [6]. To date, the expression and function of PPARs in pulmonary sarcoidosis is scantily documented. Alveolar macrophages (AM) from patients with active chronic sarcoidosis exhibited a deficiency of PPARY activity, and PPARY gene expression in BAL cells was reduced in patients with severe disease $[12,13]$. To our knowledge, the expression of PPAR $\alpha$ and PPAR $\beta / \delta$ in sarcoidosis has not been documented.

Considering the regulatory and immunomodulatory actions of PPARs, we hypothesized that down regulation of their expression in sarcoidosis may represent a mechanism leading to the promotion of inflammation. The aim of this study was to gain more insight about the expression of all three PPARs $(\alpha, \beta / \delta$ and $\gamma)$ in human AM and $\mathrm{CD} 4^{+} \mathrm{T}$ cells in LS and non-LS patients in comparison to healthy controls $(\mathrm{HC})$.

\section{Methods}

\section{Study subjects}

All included patients in this study were referred to the Lung and Allergy clinic (at Karolinska University Hospital or at Stockholm South General Hospital, Stockholm, Sweden) for an investigational work up of clinically suspected pulmonary sarcoidosis. The diagnosis of sarcoidosis in the non-Löfgren patients was established by clinicoradiographic findings compatible with the disease and in most cases by biopsies showing non-caseating epithelioid granuloma. If biopsies were negative despite typical clinicoradiographic findings the diagnosis was considered likely if BALF analysis showed a $\mathrm{CD} 4^{+} / \mathrm{CD}^{+}$ratio $>4$ and the diagnosis remained the same at follow-ups. In addition, other causes of sarcoid like diseases and reactions were reasonably excluded $[14,15]$. In Löfgren patients the diagnosis of presumptive sarcoidosis was made with high confidence based on typical clinical findings, provided there are no other explanations for the symptoms. Furthermore, the patients had BALF with a high percentage of lymphocytes and a $\mathrm{CD} 4^{+} / \mathrm{CD} 8^{+}$ratio $>4$ [16]. Written informed consent was obtained from all subjects, and the Regional Ethical Review Board (Stockholm, Sweden) approved the study.

A total of 29 healthy controls (HC) and 57 sarcoidosis patients were sequentially recruited to this study (clinical and BAL cells characteristics are summarized in Table 1). All $\mathrm{HC}$ were non-smokers, had normal lung function results, unremarkable chest X-ray, and none of them showed any signs of lower respiratory tract infection at least six weeks prior to the bronchoscopy. All patients had a clinical picture completely consistent with sarcoidosis, and they were subdivided into two groups according to their clinical phenotypes: Löfgren's syndrome (LS) and non-LS. Patients were also classified as being HLA allele DRB1*0301 (DR3) positive or DR3 negative. Twenty-seven patients had LS, $\left(74 \% \mathrm{DR}^{+}\right.$, median age 39 years (min-max: 28-56, 15 females and 12 males)). Thirty patients had non-LS (80\% DR3- ${ }^{-}$median age 47 (min-max: 27-71, 9 females and 21 males)). Only patients, who did not receive anti-inflammatory or immunosuppressive medications, were included into the study. None of the patients included in this study was on treatment with fibrates or glitazones.

The study progressed through three sequential stages. In the first stage, the expression of PPARs mRNA in total BAL cells was analyzed in $6 \mathrm{HC}$ and 16 sarcoidosis (7 LS and 9 non-LS) patients. In the second phase, the expression of PPARs mRNA in FACS (Fluorescence-activated cell sorting) sorted BAL $\mathrm{CD}^{+}{ }^{+} \mathrm{T}$ lymphocytes and $\mathrm{AM}$ were analyzed separately in a total $19 \mathrm{HC}$ and 34 sarcoidosis (17 LS and 17 non-LS) patients. In the last stage, PPARs protein expression in BAL and blood $\mathrm{CD}^{+}$- and $\mathrm{CD}^{+} \mathrm{T}$ lymphocytes and $\mathrm{AM}$ was investigated by using 
Table 1 Characterization of sarcoidosis patients and HC

\begin{tabular}{|c|c|c|c|}
\hline & Löfgren's & Non-Löfgren's & Healthy controls \\
\hline Subjects number & 27 & 30 & 29 \\
\hline Age & $39(28-56)^{* * * *}$ & $47(27-71)^{* * * *}$ & $26(18-42) x$ \\
\hline Sex, female/male & $15 / 12$ & $9 / 21$ & $15 / 14$ \\
\hline smoking history (NS/FS/OS/CS) & $20 / 5 / 2 / 0$ & 16/13/1/0 & 29/0/0/0 \\
\hline Radiograph stages (0,I, II, III, IV, ND) & 0/16/9/0/0/2 & $0 / 7 / 9 / 4 / 4 / 6$ & 29/0/0/0/0 \\
\hline HLA (DR3+/DR3-/ND) & $20 / 6 / 1$ & $3 / 24 / 3$ & ND \\
\hline \multicolumn{4}{|l|}{ BAL analysis } \\
\hline Recovery \% & $68(44-80)$ & $63,5(44-84)$ & $72(34-88)$ \\
\hline Viability \% & $95(85-99)$ & $95(78-98)$ & $95(88-98)$ \\
\hline Cell concentration $\left({ }^{*} 10^{6} / \mathrm{L}\right)$ & $225(49-588)^{* * * *}$ & $188(83,5-476)^{* * * *}$ & $90,5(29-167) x$ \\
\hline Total cell number $\left({ }^{*} 10^{6}\right)$ & $36(9-77)^{* * * *}$ & $28(10-81)^{* * *}$ & $16(5-31,5)$ \\
\hline \multicolumn{4}{|l|}{ BAL differential cell counts } \\
\hline$\%$ Macrophages & $68(39,4-91)^{* * * *}$ & $71(39,70-85)^{* * * *}$ & $87(60,8-97,2) x$ \\
\hline \% Lymphocytes & $30(8,5-57,8)^{* * * *}$ & $26(13-58,2)^{* * * *}$ & $11(2,4-33,7) a$ \\
\hline$\%$ Neutrophils & $1,0(0-5,8)$ & $1,0(0-6)$ & $1,8(0,2-6)$ \\
\hline \% Eosinophils & $0,3(0-2,5)$ & $0,3(0-4,4)$ & $0,2(0-1,6)$ \\
\hline CD4/CD8 ratio & $9,6(1,1-28)^{* * * *}$ & $5,8(1,6-33)^{* * *}$ & $2,65(0,9-4,8) \not$ \\
\hline \multicolumn{4}{|l|}{ Pulmonary function tests } \\
\hline FVC (\% of predicted value) & $90(67-120)^{* * * *}$ & $84(50-105)^{* * * *}$ & $111(86-130) x$ \\
\hline FEV1 (\% of predicted value) & $87(61-104)^{* * *}$ & $82(46-112)^{* * * *}$ & $107(86-125) \not$ \\
\hline TLC (\% of predicted value) & $92(82-123)^{* * *}$ & $85(62-186) \#$ & ND \\
\hline DLCO (\% of predicted value) & $86(66-126)$ & $82(54-130)$ & ND \\
\hline
\end{tabular}

Data are presented as median (minimum-maximum). NS: never smoker, FS: former smoker, OS: occasional smoker, CS: current smoker. Radiographic stages 0: normal, stage I: bilateral hilar lymphadenopathy (BHL), stage II: BHL and parenchymal infiltrates, stage III: parenchymal infiltrates without BHL, stage IV: signs of fibrosis. BAL: bronchoalveolar lavage; VC: vital capacity; FEV $_{1}$ : forced expiratory volume in $1 \mathrm{~s}$; DLCO: diffusing capacity of the lung for carbon monoxide; ND: not determined; a Kruskal-Wallis test was used to compare all three groups and a significant difference was only observed when LS and non-LS patients were compared with HC; \# Mann-Whitney U-test between LS and non-LS patients; ${ }^{* *}: p<0.01,{ }^{* * *}: p<0.001{ }^{* * * *}: p<0.0001$.

flow cytometry. Six $\mathrm{HC}$ and nine sarcoidosis patients (4 LS and 5 NLS) were recruited for this flow cytometry analysis. Due to limitations in numbers of BAL and blood cells available for this study, some samples of patients and $\mathrm{HC}$ could not be included in all types of analyses. However, to ensure no selection bias, all individuals were randomly included in the different experiments. The exact numbers of controls and patients in each group are indicated in the figures.

\section{Bronchoalveolar lavage (BAL) and preparation of cells}

BAL was performed as previously described [17]. Briefly, after light sedation and topical local anesthesia, a flexible fiber-optic bronchoscope (Olympus Optical Co., Tokyo, Japan) was passed trans-nasally and BAL was performed in a subsegmental bronchus in the middle-lobe. BAL was then performed by sequentially instilling and gently suctioning $50 \mathrm{ml}$ of warmed $\left(37^{\circ} \mathrm{C}\right)$ and sterile phosphatebuffered saline (PBS) solution five times. The BAL fluid aliquots were pooled and collected in a siliconized plastic vessel kept on ice at $4^{\circ} \mathrm{C}$. The recovered volume as percentage of total instilled fluid is indicated in Table 1. The BALF was gently passed through a Dacron gauze (Milipore, Cork, Ireland) and centrifuged at $400 \mathrm{~g}$ for ten minutes at $4^{\circ} \mathrm{C}$. The pellet was resuspended in PBS. The cells were counted in a Bürker chamber. The expression of cell surface antigens $(C D 3, C D 4, C D 8)$ and the $\mathrm{CD}^{+}$to $\mathrm{CD}^{+}$cell ratio were performed by flow cytometric analysis (BD FACSCanto II flow cytometer) using monoclonal antibodies against $\mathrm{CD}^{+}$(Pacific Blue Mouse Anti-human CD3, clone UCHT1; BD Biosciences), $\mathrm{CD}^{+}{ }^{+}$(APC-H7 Anti-human CD4, clone SK3; BD Biosciences), $\mathrm{CD}^{+}$(AmCyan Anti-human CD8, cloneSK1; BD Biosciences) as previously described [18].

\section{Flow cytometric sorting of BAL macrophages and} $\mathrm{CD}^{+}{ }^{+}$cells

BAL cells were stained with PE Mouse Anti-human CD4, clone RPA-T4. The stained cells were sorted by FACSVantage (BD Biosciences). BAL cells were gated on lymphocytes and macrophages and the stained $\mathrm{CD} 4^{+} \mathrm{T}$ cells and macrophages were effectively separated. The 
purity of the sorted population, which was determined by flow cytometry, was approximately $98 \%$.

\section{Flow cytometric analysis of PPAR $a, \beta / \delta, \gamma$}

To detect intracellular PPAR $\alpha, \beta / \delta, \gamma$ on a single cell level in blood and BALF cells, flow cytometry was utilized. The cells were fixed and permeabilized with the BD Pharmingen $^{\text {Tn }}$ Transcription Factor Buffer set (BD Biosciences). The following primary antibodies and isotypes controls were added: Mouse monoclonal [3B6/PPAR] to PPAR alpha - ChIP Grade (ab2779), Mouse IgG2b [PLPV219] - Isotype Control (ab91366), Mouse monoclonal to PPAR delta (ab58137), Mouse IgG2a [ICIGG2A] -
Isotype Control (ab91361), Mouse monoclonal [A3409A] to PPAR gamma $1+2$ - ChIP Grade (ab41928) and Mouse IgG1 [ICIGG1] - Isotype Control (ab91353). The following secondary antibody was used: Goat polyclonal Secondary Antibody to Mouse IgG - H\&L (DyLight ${ }^{\circ} 488$ ), preadsorbed (ab96879) (Abcam). Cell surface staining with anti- CD3, CD4, and CD8 was performed after blockade with mouse serum. Cells were analyzed on BD FACSCanto II flow cytometer (BD Bioscience) and data were processed using the web-based application Cytobank [19] (Cytobank, Inc). Alveolar macrophages and lymphocytes were gated based on characteristic light scatter properties. Within the lymphocyte gate, a

(a)
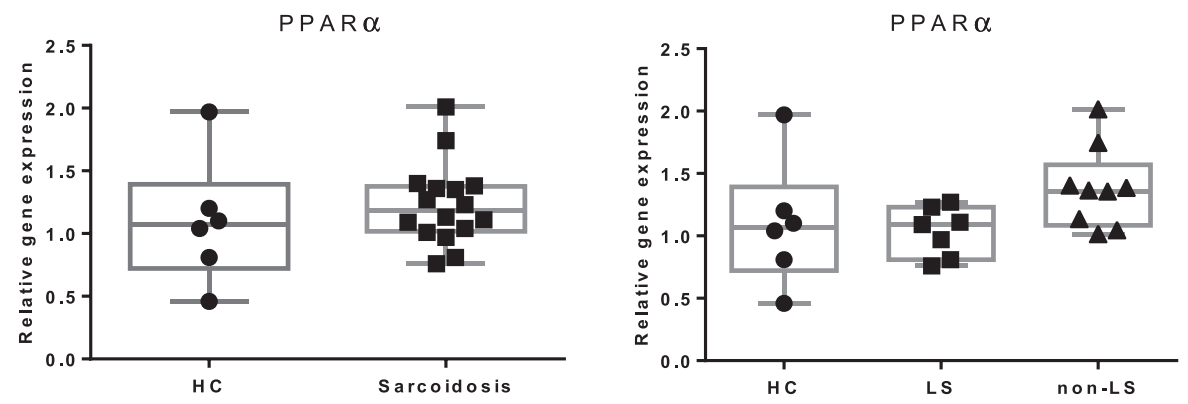

(b) PPAR $\beta / \delta$
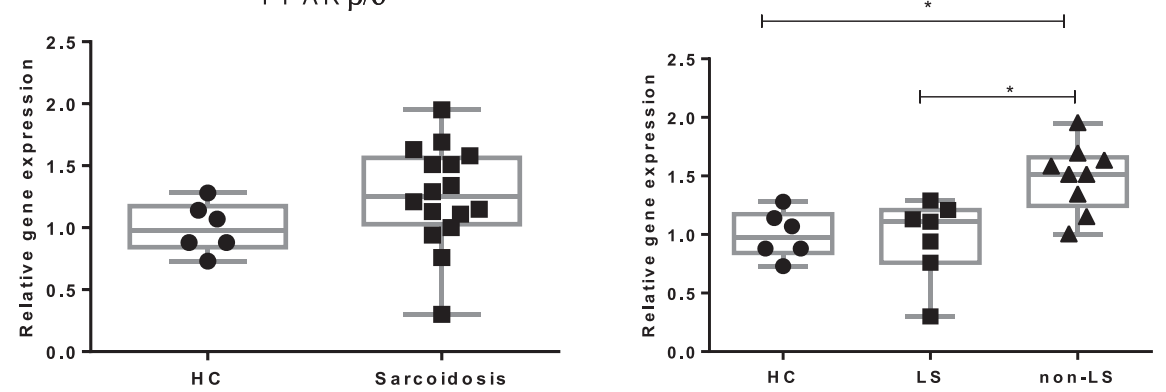

(c)
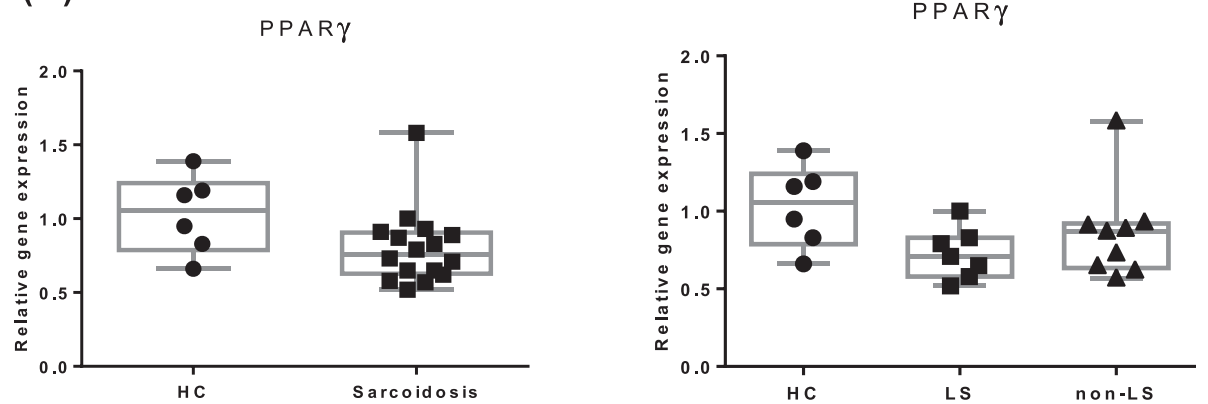

Figure 1 The relative mRNA expression in total BAL cells of (a) PPARa, (b) PPAR $\beta / \delta$ and (c) PPARY of HC ( $n=6)$, patients with sarcoidosis $(n=16)$ and patients subgroups $(L S=7$, non-LS $=9$ ) are shown. The boxes show median (25th-75th percentiles) values and the whiskers show minimum and maximum values. Each symbol represents an individual patient. 
further gate was set on $\mathrm{CD}^{+}$lymphocytes. Within the $\mathrm{CD}^{+}$gate, further gates were set on $\mathrm{CD} 4^{+}$and $\mathrm{CD}^{+}$cells to identify $\mathrm{CD}^{+} \mathrm{CD}^{+}$and $\mathrm{CD}^{+} \mathrm{CD}^{+} \mathrm{T}$ cells respectively. PPARs were then measured in $\mathrm{CD}_{4}^{+}$and $\mathrm{CD} 8^{+} \mathrm{T}$ cells and macrophages. Quantitative levels of PPARs, expressed as median fluorescence intensity (MFI), were determined after subtraction of the background level calculated from samples labelled with isotype control antibodies.
RNA extraction and CDNA synthesis

Depending on the cells count $\left(\leq 5 \times 10^{5}\right.$ or $\left.\geq 10^{6}\right)$ total RNA was isolated using the RNAqueous-micro kit or the RNAqueous kit (Ambion ${ }^{\odot}$ ) according to the manufacturer's instructions. The quantity of total RNA was analysed using NanoDrop ND-1000Spectrophotometer (NanoDrop Technologies, Wilmington, DE, USA). To synthesize cDNA the high capacity RNA-to-cDNA kit
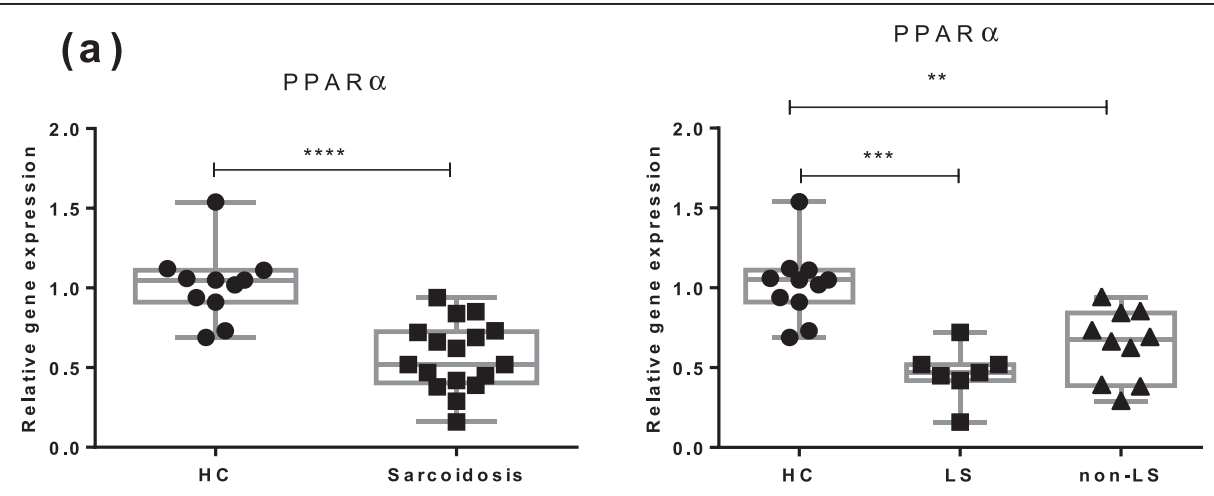

(b)

PPAR $\beta / \delta$

PPAR $\beta / \delta$
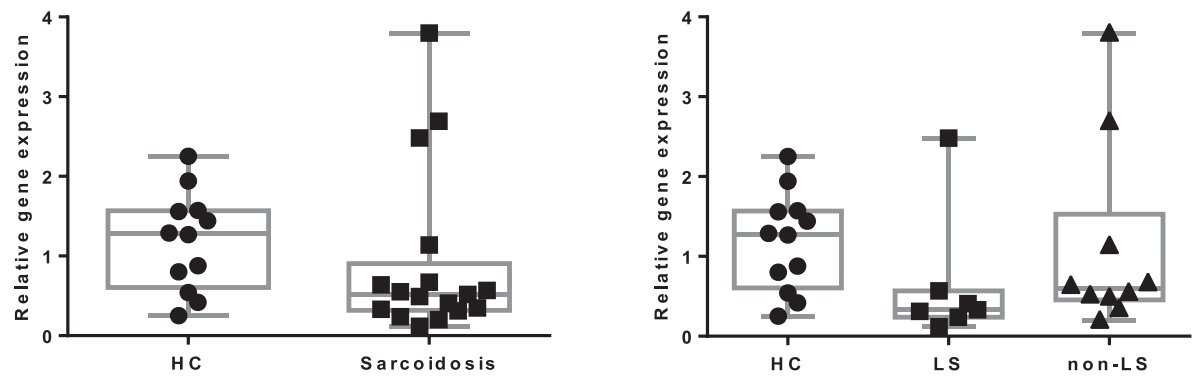

(c)

PPAR $\gamma$
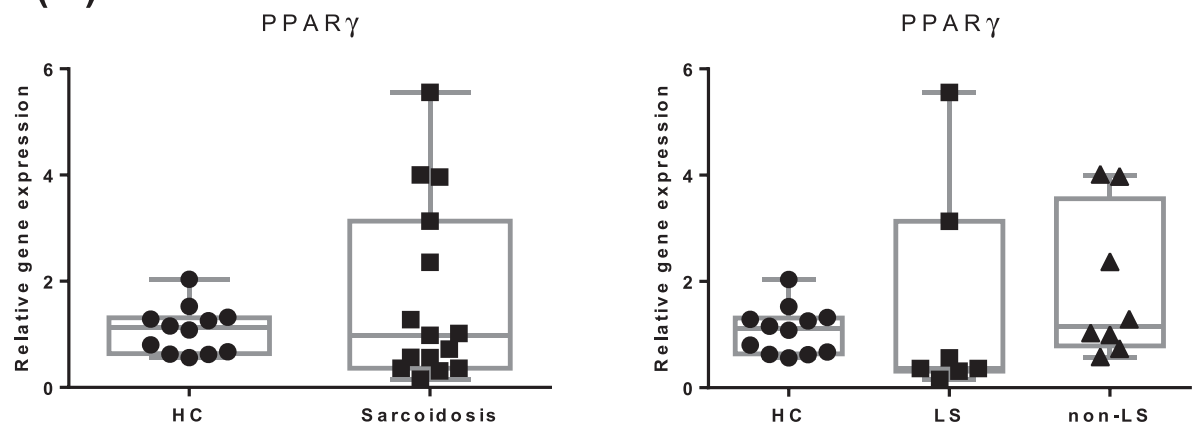

Figure 2 The relative mRNA expression FACS-sorted BAL CD4 ${ }^{+}$T cells of (a) PPARa, (b) PPAR $\beta / \delta$ and (c) PPARY of HC $(n=12)$, patients with sarcoidosis $(n=17)$ and patients subgroups $(L S=7, n o n-L S=10)$ are shown. The boxes show median (25th-75th percentiles) values and the whiskers show minimum and maximum values. Each symbol represents an individual patient. 
(Invitrogen ${ }^{\mathrm{nx}}$ ) was used according to the manufacturer's instructions.

\section{Analysis of PPAR $\alpha, \beta / \delta, \gamma$ gene expression by real-time} PCR

Real-time quantitative PCR (RT-PCR) was performed using gene-specific fluorogenic assays (TaqMan; Applied Biosystems) and an ABI Prism 7700 Sequence Detection System (Applied Biosystem). Proteasome Subunit, Beta Type, 2 (PSMB2) was used as a reference gene to normalize
RT-PCR in BAL cells in sarcoidosis [20]. For relative quantification of PPARs gene expression in BAL cells, the comparative $\mathrm{Ct}$ method was used according to the formula $2^{-\Delta \Delta \mathrm{Ct}}[21]$. In the first step, the Ct of the target gene (PPAR $\alpha, \beta / \delta, \gamma)$ was normalized to the endogenous control (PSMB2). In the second step, normalization to the median value of PPAR $(\alpha, \beta / \delta, \gamma)$ gene expression in a HC group (calibrator sample) was performed. All samples were run in duplicates to ensure the validity of the experiment. The following primers were used: PSMB2 (Hs01002946_m1),
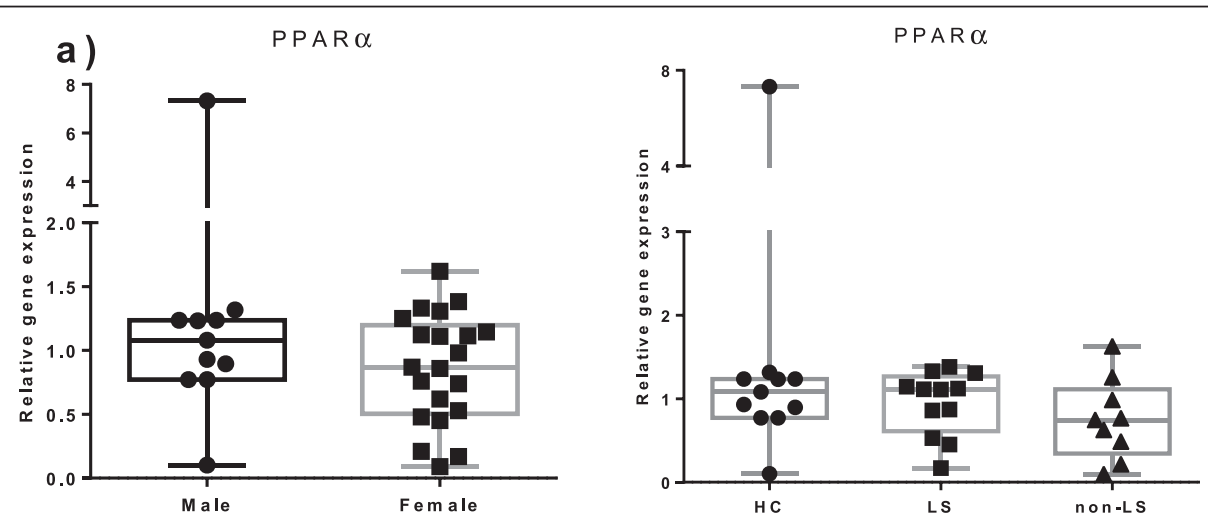

b) $\quad \operatorname{PPAR} \beta / \delta$
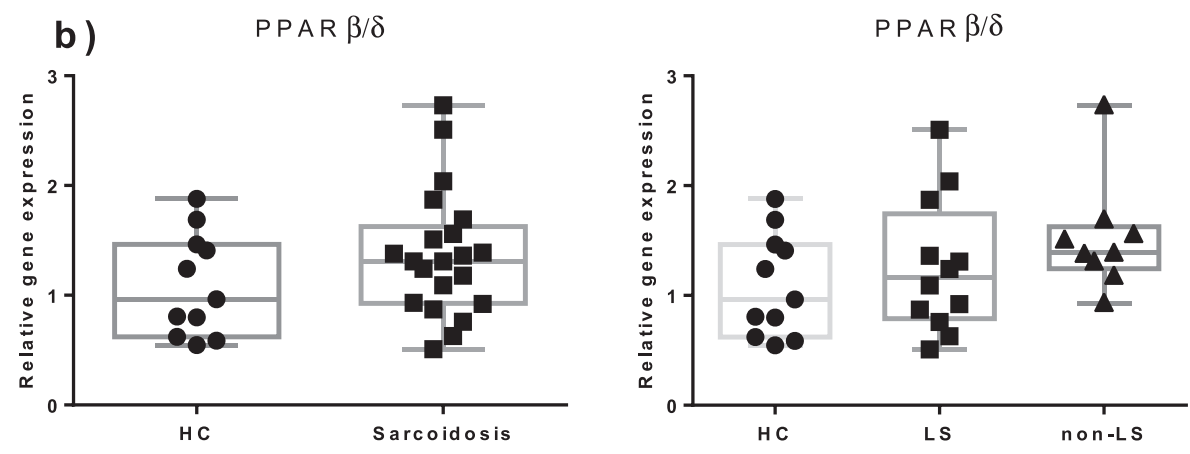

c)
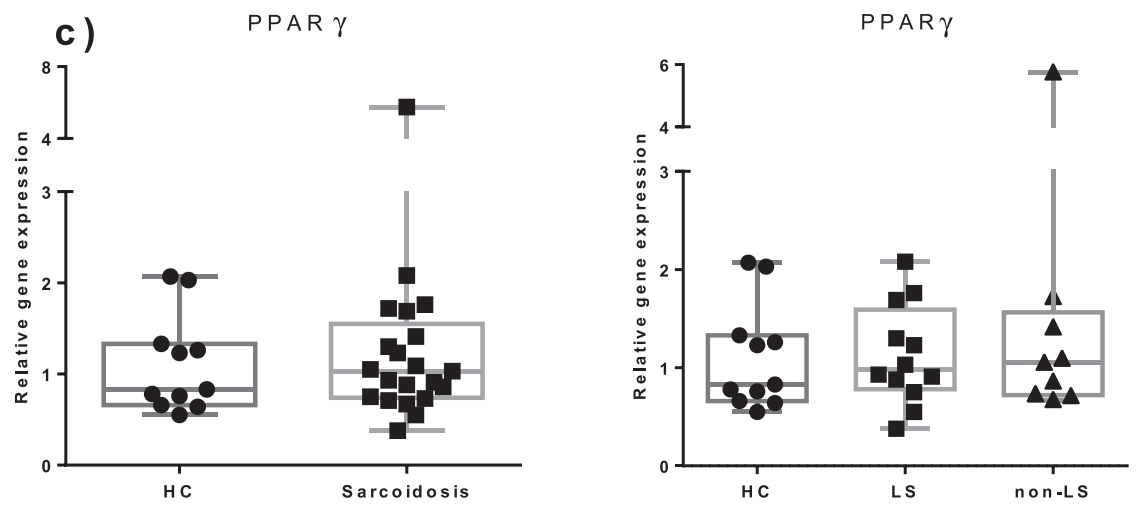

Figure 3 The relative mRNA expression in FACS-sorted BAL macrophages of (a) PPARa, (b) PPAR $\beta / \delta$ and (c) PPARY of HC ( $n=11)$, patients with sarcoidosis $(n=21)$ and patients subgroups $(L S=12, n o n-L S=9)$ are shown. The boxes show median (25th-75th percentiles) values and the whiskers show minimum and maximum values. Each symbol represents an individual patient. 
PPAR $\alpha$ (Hs00947539_m1), PPAR $\delta$ (Hs00602622_m1), PPAR (Hs00234592_m1) (Applied Biosystems).

\section{Statistical analysis}

The nonparametric Mann-Whitney test or Kruskal-Wallis test was used to compare the distributions (medians) of two or three unmatched groups respectively. In the case of Kruskal-Wallis test, the Dunn's post test was used to compare the difference between two groups. Wilcoxons signed ranks test was used to calculate differences in PPARs expression in BAL and blood $\mathrm{CD} 4^{+} \mathrm{T}$ cells. Values of $\mathrm{p}<0,05$ $(*)$ were regarded as significant. All statistical tests were performed using the GraphPad PRISM version 6.04 (GraphPad Software, Inc).

\section{Results}

PPARs mRNA expression in BAL fluid and blood cells

We first investigated PPARs mRNA expression levels in total BAL cells in HC and sarcoidosis patients (Figure 1). We found no significant differences in PPAR $\alpha, \operatorname{PPAR} \beta / \delta$ and PPAR $\gamma$ mRNA expression between sarcoidosis patients and HC. An increased expression of PPAR $\beta / \delta$ mRNA was noted in non-LS patients compared with LS patients and $\mathrm{HC}$ (Figure 1b).

We then investigated mRNA expression in FACS sorted BAL CD4 ${ }^{+} \mathrm{T}$ cells (Figure 2). Here we noticed a significantly lower PPAR $\alpha$ mRNA expression in sarcoidosis patients compared with HC (Figure 2a). This reduction was noted in both LS patients and non-LS patients.

We also explored PPARs mRNA expression in FACS sorted AM (Figure 3). We noticed no significant differences in PPAR $\alpha$ PPAR $\delta$ and PPAR $\gamma$ expression between sarcoidosis patients, including patient's subgroups (LS and non-LS) and HC.
Flow cytometric analysis of PPARs protein expression in blood and BAL cells

An illustrative histogram overlay of PPAR $\alpha$ expression in BAL CD4 $4^{+} \mathrm{T}$ cells in a patient with LS and the gating hierarchy is shown in (Figure 4). A significantly lower expression of PPAR $\alpha$ in non-LS patients was detected as compared with LS patients (Figure 5a). This was observed also in the $\mathrm{BAL} \mathrm{CD}^{+}{ }^{+} \mathrm{T}$ subset (Additional file 1: Figure S1 a).

In peripheral blood $\mathrm{CD} 4^{+} \mathrm{T}$ cells as well $\mathrm{CD} 8^{+} \mathrm{T}$ cells, non-LS patients had a significantly lower expression of PPAR $\alpha$ as compared with LS patients (Figure 6a) and (Additional file 2: Figure $\mathrm{S} 2$ a). In both $\mathrm{CD} 4^{+}$and $\mathrm{CD} 8^{+}$ $\mathrm{T}$ cells of peripheral blood, a strong trend toward a lower expression of PPAR $\gamma$ was also observed in non-LS patients as compared with LS patients (Figure 6c) and Additional file 2: Figure S2 c). This difference was statistically significant $(\mathrm{p}<0.05)$ when directly comparing LS and non-LS patients.

A representative histogram overlay of PPAR $\alpha$ expression in AM and the related FACS plot of BAL cells with gating of AM is shown in (Figure 7). As shown in Figure 8, we did not observe any significant difference in PPARs expression in AM of sarcoidosis patients from $\mathrm{HC}$.

\section{Comparison of PPARa, PPAR $\beta / \delta$ and PPAR $\gamma$ expression in $\mathrm{BAL}$ and blood $\mathrm{CD} 4^{+} \mathrm{T}$ cells in the same individual}

Comparison of MFI between PPAR $\alpha, \operatorname{PPAR} \beta / \delta$ and PPAR $\gamma$ expression in BAL and blood $\mathrm{CD} 4^{+} \mathrm{T}$ cells in the same individual revealed a statistically significantly lower expression of PPAR $\beta / \delta$ in blood $C D 4^{+} \mathrm{T}$ cells as compared with BAL $\mathrm{CD} 4^{+} \mathrm{T}$ cells of healthy individuals. The same tendency was observed for PPAR $\beta / \delta$ expression in LS and non-LS patients (Additional file 3: Figure S3 b); the difference was statistically significant when all (a)

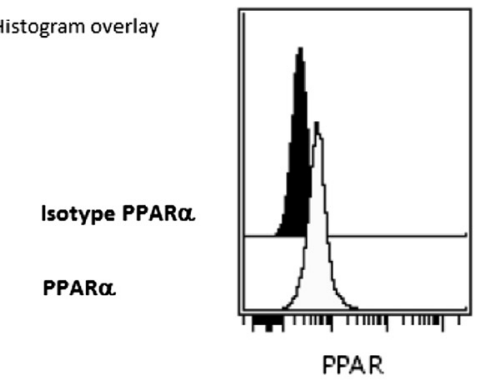

(b) Gating hierarchy
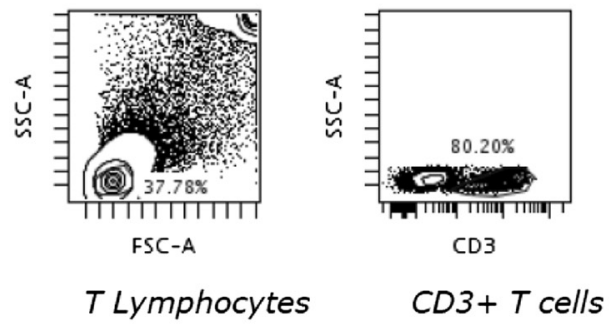

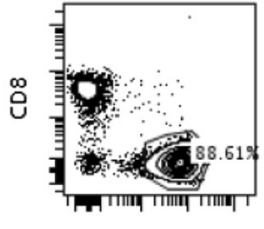

$\mathrm{CD} 4$

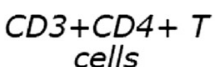

Calculated Raw values of Medians using X-Axis channel(s):

\begin{tabular}{|l|l|}
\hline Isotype PPAR $\alpha$ & 233.38 \\
\hline PPAR $\alpha$ & 523.34 \\
\hline
\end{tabular}

Figure 4 Representative histogram overlay (a) -in a patient with LS syndrome- of PPARa expression in BAL CD4 ${ }^{+}$T cells and the gating plots on $\mathrm{CD}^{+} \mathbf{T}$ cells (b). Black histogram is the isotype control; light gray histogram is the anti-PPARa. The x-axis of each histograms represents fluorescence intensity of the isotype and PPARa on a logarithmic scale, and the $y$-axis represents the total number of events. The values of the medians using the $x$-axis channels are presented in the table. 

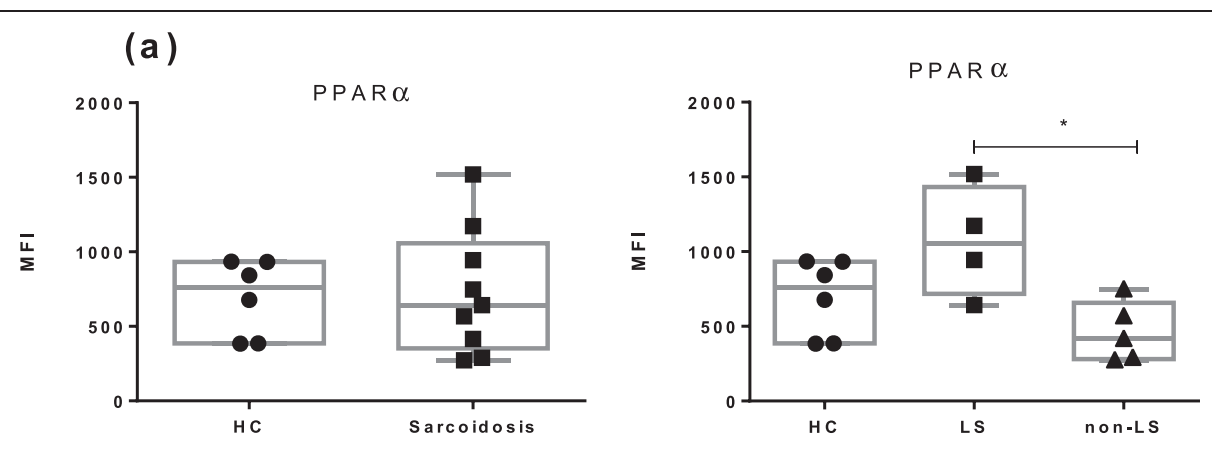

(b)

PPAR $\beta / \delta$

PPAR $\beta / \delta$
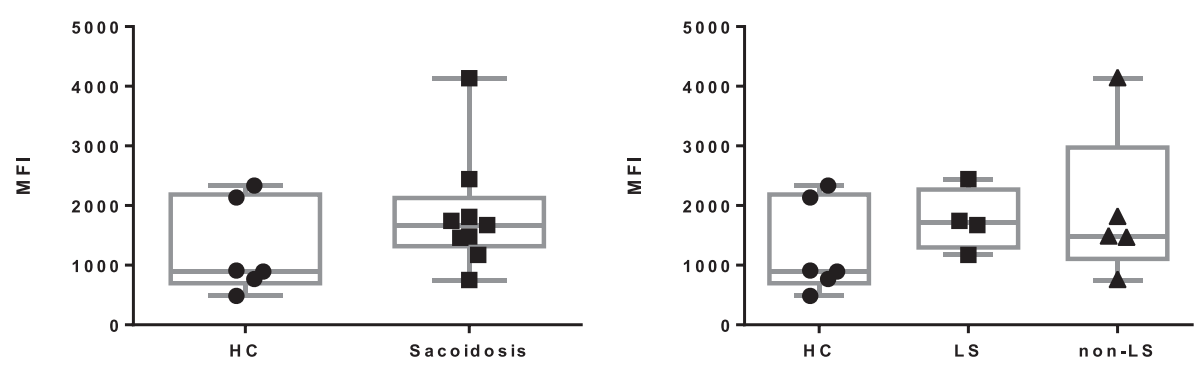

(c)

PPAR $\gamma$

PPAR $\gamma$
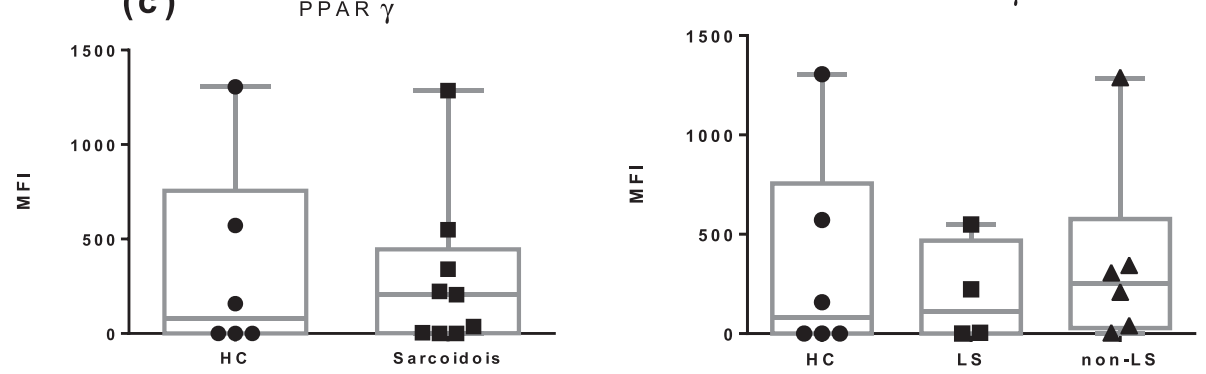

Figure 5 Flow cytometric analysis of PPARs expression in BAL CD4 ${ }^{+}$T cells. (a) PPARa. (b) PPARß/ $\delta$. (c) PPARY. HC: $(n=6)$; LS patients $(n=4)$; non-LS patients $(n=5)$. MFI: median fluorescence intensity. The boxes show median (25th-75th percentiles) values and the whiskers show minimum and maximum values. Each symbol represents an individual patient.

sarcoidosis patients were analyzed together. The expressions of PPAR $\alpha$, and PPAR $\gamma$ were comparable in BAL and blood $\mathrm{CD}_{4}^{+} \mathrm{T}$ cells in the same individual in all groups.

\section{Discussion}

Recognizing that PPARs have an important role in controlling inflammatory responses [7], we investigated the expression of PPARs in total BAL cells, in BAL AM and in BAL and in peripheral blood $\mathrm{CD}_{4}^{+}$and $\mathrm{CD}^{+} \mathrm{T}$ cells from healthy controls ( $\mathrm{HC}$ ) and from sarcoidosis patients with or without Löfgren's syndrome (LS and non-LS). Our data shows for the first time, that PPAR $\alpha$ expression is downregulated in $\mathrm{BAL}$ and blood $\mathrm{CD} 4^{+}$ and $\mathrm{CD}^{+} \mathrm{T}$ cells in non-LS patients. In addition, the expression of PPAR $\gamma$ was found to be reduced in blood $\mathrm{CD}^{+}$and $\mathrm{CD}^{+} \mathrm{T}$ cells in non-LS patients compared to LS patients.

These finding are consistent with prior published results of PPAR $\alpha$ and PPAR $\gamma$ expression in other inflammatory disorders. PPAR $\alpha$ expression was reported to be reduced in the inflamed lung of LPS- or allergen-exposed mice. Administration of fenofibrate (an PPAR $\alpha$ agonist) increased PPAR $\alpha$ expression while decreasing the inflammatory response [22]. Several studies showed that PPAR $\alpha$ expression is reduced in inflamed skin [23]. Additionally, activation of PPAR $\alpha$ with fenofibrate provides antiinflammatory activity in allergic asthma [24]. Klotz et al., 

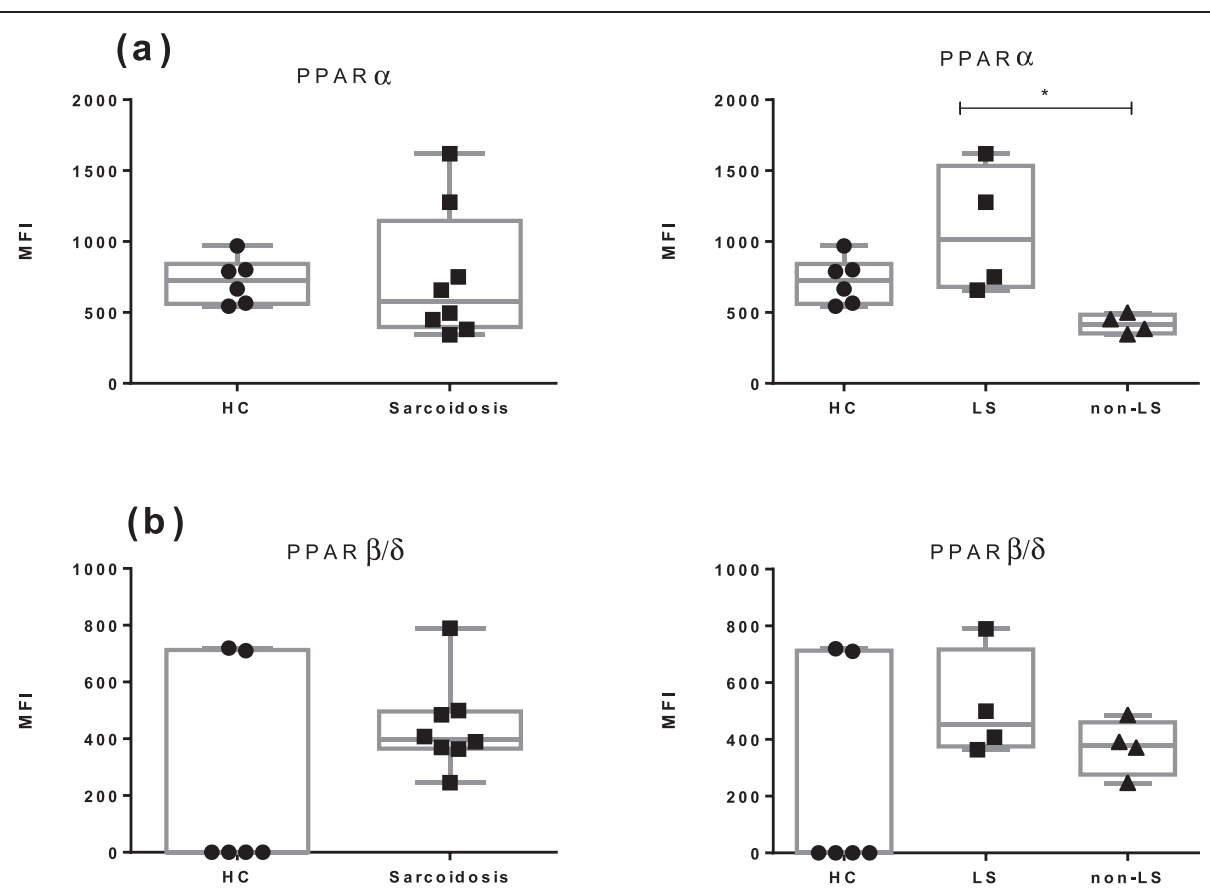

(c)
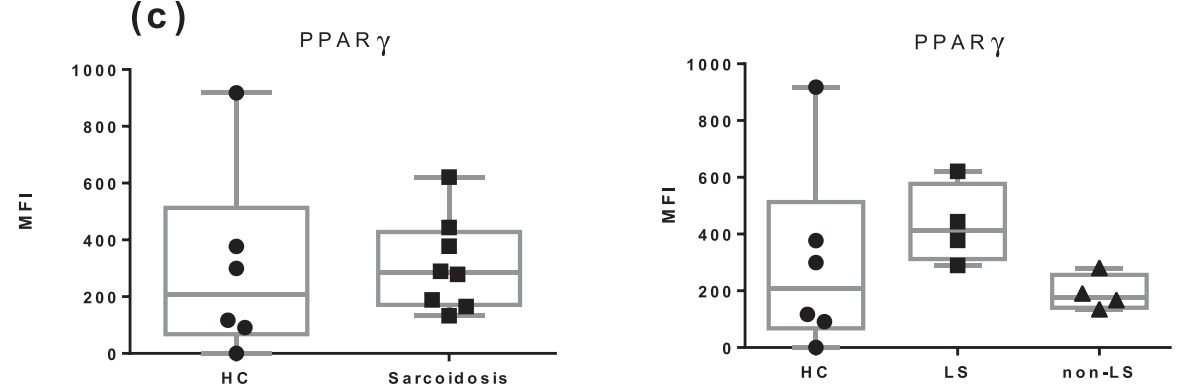

Figure 6 Flow cytometric analysis of PPARs expression in peripheral blood CD4 ${ }^{+}$T cells. (a) PPARa. (b) PPARB/ $\delta$. (c) PPARY. HC ( $\left.n=6\right)$; LS patients $(n=4)$; non-LS patients $(n=4)$. MFI: median fluorescence intensity. The boxes show median (25th-75th percentiles) values and the whiskers show minimum and maximum values. Each symbol represents an individual patient.

demonstrated that PPAR $\gamma$ protein expression is significantly reduced in peripheral blood mononuclear cells (PBMCs) in multiple sclerosis patients [25]. PPAR $\gamma$ expression is notably decreased in the colon of patients with ulcerative colitis [26]. Furthermore, PPARY is down-regulated in lung tissue and epithelial cells of COPD patients [27].

Notably, PPAR $\alpha$ and PPARY ligand activation decreases the expression of inflammatory cytokines, such as IFN $\gamma$ and TNF $\alpha$ by Th1 cells $[10,11]$. Previous studies from our group showed decreased expression of Th1 cytokines (INF $\gamma$ and TNF $\alpha$ in BAL fluid cells in HLA-DR3 ${ }^{+}$sarcoidosis patients (typically with Löfgren's syndrome) as compared with HLA-DR3 ${ }^{-}$patients [28]. Consequently, the reduced expression of PPAR $\alpha$ in non-LS patients could contribute to the more pronounced Th1 response with elevated Th1 cytokines. The reduced expression of PPAR $\alpha$ in $\mathrm{CD}^{+}$and $\mathrm{CD}^{+} \mathrm{T}$ cells in non-LS patients could contribute to a non-resolving disease and a worse prognosis in these patients compared to patients with LS.

Interestingly, PPAR $\alpha$-deficient $\mathrm{T}$ regulatory cells (Treg) lack suppressive capacity [29]. PPAR $\alpha$ or PPAR $\gamma$ deficient mice showed reduced Treg recruitment to the sites of inflammation [30,29]. This could contribute to the reduced quantity of Treg cells in BALF observed in some studies $[31,32]$ and the dysfunctional activity of these cells in sarcoidosis patients [33].

Th17 cells have been implicated also in sarcoidosis, although with conflicting results regarding their frequency $[32,34,35]$, but the majority of BALF Th17 cells produce both IL-17 and INFY (Th17 INF ${ }^{+}$) [32,36]. Th17 INF $\gamma^{+}$cells are thought to be pathogenic in several autoimmune diseases [37]. The activation of PPAR $\alpha$ or $\gamma$ reduces INF $\gamma$ as well as IL-17 production in T cells [38,39]. In addition, PPAR $\gamma$ activation in $\mathrm{CD}^{+} \mathrm{T}$ cells 


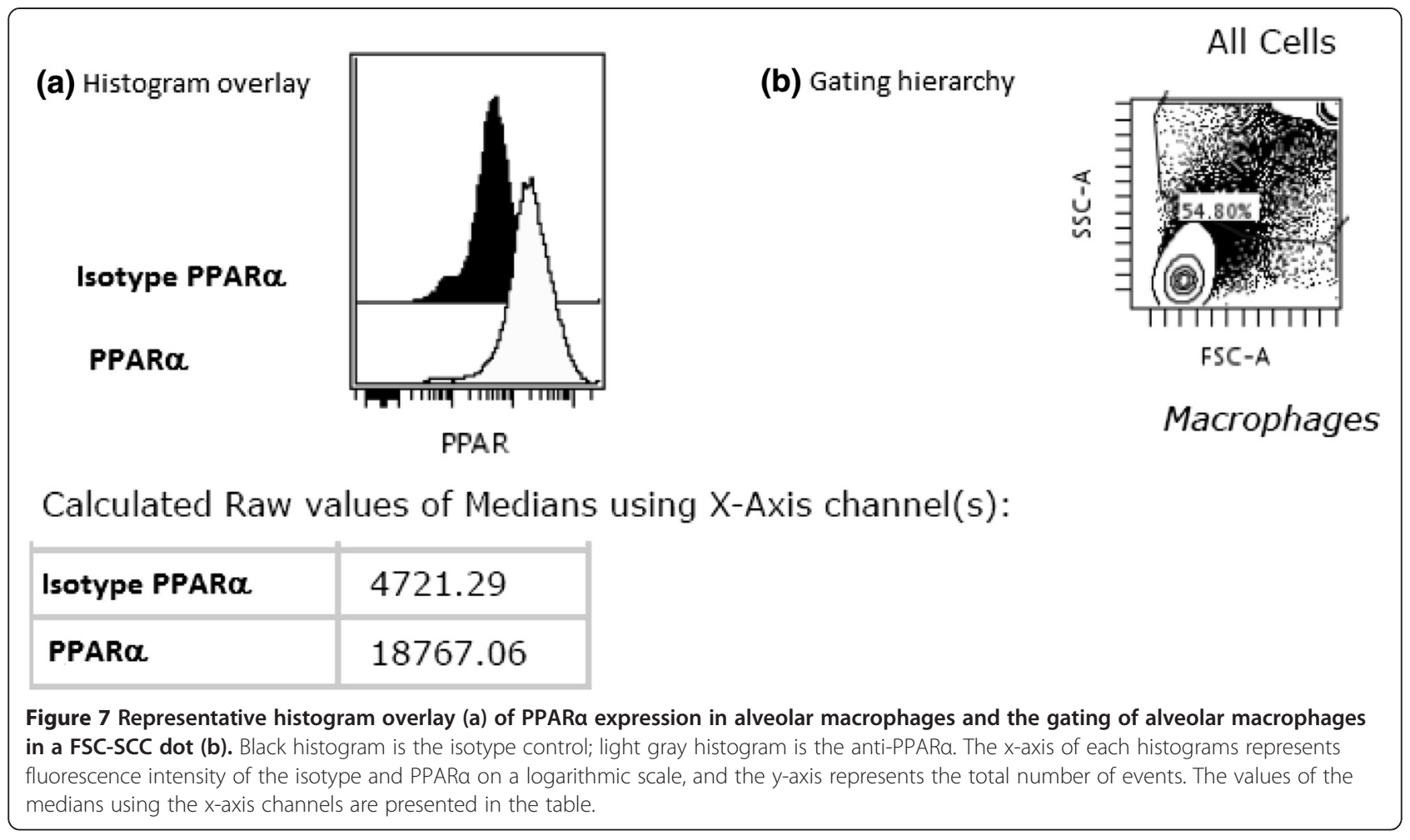

selectively suppressed Th17 differentiation [40]. Thus, PPAR $\alpha$ or PPAR $\gamma$ could be potential therapeutic targets in sarcoidosis.

Our study shows that the expression of PPAR $\alpha$ mRNA is reduced in BAL $\mathrm{CD}^{+}{ }^{+} \mathrm{T}$ cells in both $\mathrm{LS}$ and non-LS patients, but the expression of PPAR $\alpha$ protein in LS patients is to some degree higher or at least comparable with the expression of PPAR $\alpha$ protein in HC. This discrepancy highlights the importance of analyzing PPARs expression on both mRNA and protein level. RT-PCR assesses mRNA levels, which may be subject to post translational modifications that prevent subsequent protein production of functional proteins. In humans, the correlation between mRNA and protein concentration is very modest [41]. Our study utilizes flow cytometry to investigate the intracellular PPARs-protein expression at the level of an individual cell and the quantification of PPARs-protein by evaluation of MFI [42].

The role and expression of PPAR $\beta / \delta$ in inflammatory cells and in pulmonary disease is less well-established [6]. We found that PPAR $\beta / \delta$ mRNA expression is higher in total BAL cells in non-LS patients compared to LS patients and $\mathrm{HC}$, and a tendency towards higher PPAR $\delta$ protein expression in blood $\mathrm{CD}^{+}$and $\mathrm{CD}^{+} \mathrm{T}$ cells in sarcoidosis patients. $\mathrm{N}$ al Yacoub et al., showed that PPAR $\delta$ is expressed both at mRNA and the protein level in human T cells, and that INF- $\alpha$ but not TCR stimulation causes increased expression of PPAR $\delta$ mRNA in peripheral human T cells [11]. Again, ligand activated
PPARS repress the production of INF $\gamma$ and IL-17 in T cells [43].

The similar levels of PPARs expression in both $\mathrm{CD}_{4}^{+}$ and $\mathrm{CD}^{+} \mathrm{T}$ cells in this study are not unique for these transcription factors and have been documented for other transcription factors such as p-STAT1 and p-STAT6 [44].

Our data show that PPARs mRNA and protein expression in $\mathrm{AM}$ is comparable with $\mathrm{HC}$ in sarcoidosis patients. In contrast to a previous finding [12] we could not verify that PPARy expression is reduced in whole BAL cells or AM from patients with sarcoidosis. An explanation for this difference could be clinical differences in the study populations, since PPAR $\gamma$ gene expression in BAL cells seems only to be reduced in patients with severe and treatment requiring sarcoidosis [13]. This may affect the T-cell driven inflammation, since deletion of PPAR $\gamma$ in alveolar macrophages is associated with Th1 pulmonary inflammatory response [45].

Our results suggest that the reduced expression of PPAR $\alpha$ and PPAR $\gamma$ contribute to the persistent T-cell driven immunoresponse noted in non-resolving sarcoidosis, common in non-LS patients. The lower expression of these transcription factors in T cells from non-LS patients is in agreement with our previous demonstration of higher IFN $\gamma$ expression in BAL T cells in that patient group. It is worth mentioning that studies have not evidently demonstrated that corticosteroids or any other therapy prevents progression or fibrosis $[46,47]$. The role of TNF-blocking agents in treating sarcoidosis is less 

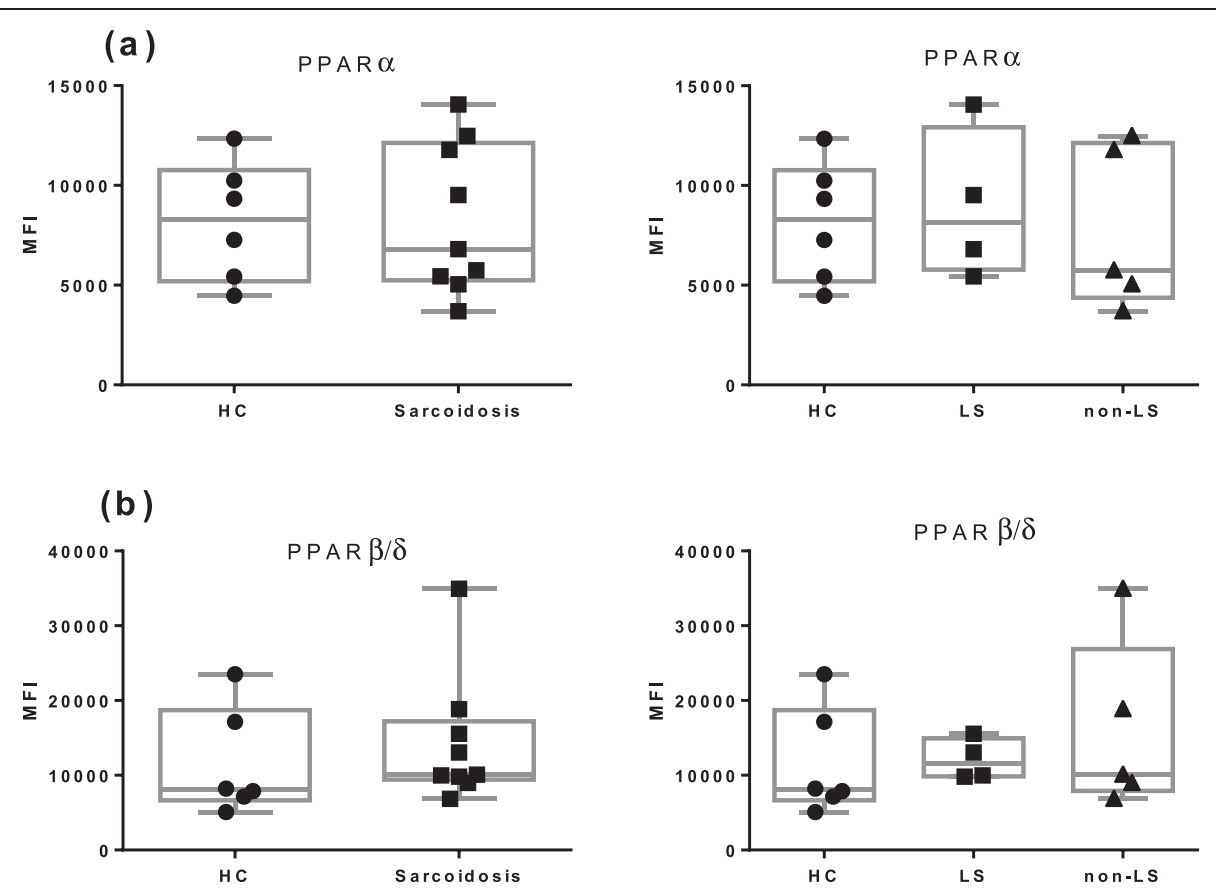

(c) PPAR $\gamma$

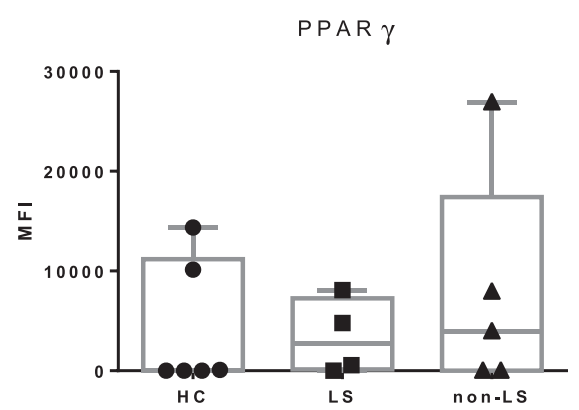

Figure 8 Flow cytometric analysis of PPARs expression in alveolar macrophages. (a) PPARa. (b) PPARß/ס. (c) PPARY. HC ( $n=6$ ); LS patients $(n=4)$; non-LS patients $(n=5)$. MFI: median fluorescence intensity. The boxes show median (25th-75th percentiles) values and the whiskers show minimum and maximum values. Each symbol represents an individual patient.

clear and modulation of one cytokine is unlikely to resolve all aspects of the disease [15]. PPARs could be possibly novel targets for regulating the inflammatory processes in sarcoidosis, and continued research may result in an alternative approach to the treatment. Indeed, a clinical trial showed that short-term treatment with rosiglitazone (PPARY agonist) is effective in patients with mild to moderately active ulcerative colitis [48]. In addition, an investigative clinical trial to explore the effect of rosiglitazone, has shown modest improvements in lung function measurements in a group of smokers with mild to moderate asthma [49]. Since fibrate drugs such as gemfibrozil are ligands for PPAR $\alpha$, the reduced expression of PPAR $\alpha$ in T cells of sarcoidosis patients without LS may suggest that this class of drugs may also become candidate for treatment of sarcoidosis.

\section{Additional files}

Additional file 1: Figure S1. Flow cytometric analysis of PPARS

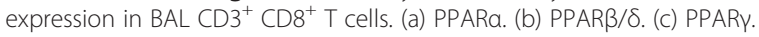
HC $(n=6)$; LS patients $(n=4)$; non-LS patients $(n=4)$. The boxes show median (25th-75th percentiles) values and the whiskers show minimum and maximum values. Each symbol represents an individual patient.

Additional file 2: Figure S2. Flow cytometric analysis of PPARs expression in peripheral blood $\mathrm{CD} 3^{+} \mathrm{CD} 8^{+} \mathrm{T}$ cells. (a) PPARa. (b) PPARß/ $\delta$. (c) PPARY. HC $(n=6)$; LS patients $(n=4)$; non-LS patients $(n=4)$. The boxes show median (25th-75th percentiles) values and the whiskers show minimum and maximum values. Each symbol represents an individual patient.

Additional file 3: Figure S3. Comparison of PPARa, PPAR $\beta / \delta$ and PPARY expression between BAL and blood $\mathrm{CD}^{+} \mathrm{T}$ cells in the same individual. MFI: median fluorescence intensity. ${ }^{*} p<0.05$, Wilcoxon's signed ranks test). HC $(n=6)$; LS patients $(n=4)$; non-LS patients $(n=4)$.

\section{Competing interests}

The authors declare that they have no competing interests. 


\section{Authors' contributions}

MAAH conceived and coordinated the study, participated in recruitment of healthy controls, participated in the bronchoscopy in healthy controls, performed patient material collection, performed lab experiments and data analysis, and wrote the manuscript. AE participated in study planning, participated in recruitment of patients, and judgmentally reviewed the manuscript. JG participated in study planning, recruitment of patients and critically reviewed the manuscript. JW co-designed and coordinated the study, and supervised the writing of the manuscript. All authors read and approved the final manuscript.

\section{Acknowledgements}

We would like to thank Benita Dahlberg, Helene Blomqvist, Gunnel de Forest and Margitha Dahl for excellent technical assistance. The authors thank Farah Idali and Maria Wikén for assistance with flow cytometric cell sorting and RNA extraction, and also Michael Hagemann-Jensen for assistance with control experiments. The study was supported by grants from the Swedish Heart Lung Foundation, The Swedish Research Council, through the regional agreement on medical training and clinical research (ALF) between Stockholm County Council and Karolinska Institutet, The King Oscar II Jubilee Foundation, Karolinska Institutet and The Mats Kleberg Foundation.

\section{Received: 26 November 2014 Accepted: 20 March 2015} Published online: 09 April 2015

\section{References}

1. Valeyre D, Prasse A, Nunes H, Uzunhan Y, Brillet PY, Muller-Quernheim J. Lancet. 2014;383:1155-67. doi:10.1016/S0140-6736(13)60680-7.

2. Touitou I. Inheritance of autoinflammatory diseases: shifting paradigms and nomenclature. J Med Genet. 2013;50(6):349-59. doi:10.1136/jmedgenet-2013-101577.

3. Grunewald J. Review: role of genetics in susceptibility and outcome of sarcoidosis. Semin Respir Crit Care Med. 2010;31(04):380-9. doi:10.1055/s-0030-1262206.

4. Bonifazi M, Bravi F, Gasparini S, La Vecchia C, Gabrielli A, Wells AU, et al. Sarcoidosis and cancer risk: systematic review and meta-analysis of observational studies. Chest. 2015;147(3):778-91. doi:10.1378/chest. 14-1475.

5. Askling J, Grunewald J, Eklund A, Hillerdal G, Ekbom A. Increased risk for cancer following sarcoidosis. Am J Respir Crit Care Med. 1999;160(5 Pt 1):1668-72. doi:10.1164/ajrccm.160.5.9904045.

6. Belvisi $M G$, Hele DJ. Peroxisome proliferator-activated receptors as novel targets in lung disease. Chest. 2008;134(1):152-7. doi:10.1378/chest. 08-0019.

7. Daynes RA, Jones DC. Emerging roles of ppars in inflammation and immunity. Nat Rev Immunol. 2002;2(10):748-59. doi:10.1038/nri912.

8. Grimaldi PA. Peroxisome proliferator-activated receptors as sensors of fatty acids and derivatives. Cell Mol Life Sci. 2007;64(19-20):2459-64. doi:10.1007/s00018-007-7278-5.

9. Poulsen L, Siersbaek M, Mandrup S. PPARs: fatty acid sensors controlling metabolism. Semin Cell Dev Biol. 2012;23(6):631-9. doi:10.1016/ j.semcdb.2012.01.003

10. Straus DS, Glass CK. Anti-inflammatory actions of PPAR ligands: new insights on cellular and molecular mechanisms. Trends Immunol. 2007;28(12):551-8. doi:10.1016/j.it.2007.09.003.

11. al Yacoub N, Romanowska M, Krauss S, Schweiger S, Foerster J. PPARdelta is a type 1 IFN target gene and inhibits apoptosis in T cells. J Invest Dermatol. 2008;128(8):1940-9. doi:10.1038/jid.2008.32

12. Culver DA, Barna BP, Raychaudhuri B, Bonfield TL, Abraham S, Malur A, et al. Peroxisome proliferator-activated receptor gamma activity is deficient in alveolar macrophages in pulmonary sarcoidosis. Am J Respir Cell Mol Biol. 2004;30(1):1-5. doi:10.1165/rcmb.2003-0304RC.

13. Barna BP, Culver DA, Abraham S, Malur A, Bonfield TL, John N, et al. Depressed peroxisome proliferator-activated receptor gamma (PPargamma) is indicative of severe pulmonary sarcoidosis: possible involvement of interferon gamma (IFN-gamma). Sarcoidosis Vasc Diffuse Lung Dis. 2006:23(2):93-100.

14. Statement on sarcoidosis. Joint statement of the American thoracic society (ATS), the European respiratory society (ERS) and the world association of sarcoidosis and other granulomatous disorders (WASOG) adopted by the ATS board of directors and by the ERS executive committee, February 1999. Am J Respir Crit Care Med. 1999;160(2):736-55. doi:10.1164/ajrccm.160.2.ats4-99.
15. Baughman RP, Culver DA, Judson MA. A concise review of pulmonary sarcoidosis. Am J Respir Crit Care Med. 2011;183(5):573-81. doi:10.1164/rccm.201006-0865Cl.

16. Costabel U, Bonella F, Ohshimo S, Guzman J. Diagnostic modalities in sarcoidosis: BAL, EBUS, and PET. Semin Respir Crit Care Med. 2010;31(04):404-8. doi:10.1055/s-0030-1262207.

17. Eklund A, Blaschke E. Relationship between changed alveolar-capillary permeability and angiotensin converting enzyme activity in serum in sarcoidosis. Thorax. 1986;41(8):629-34.

18. Grunewald J, Berlin M, Olerup O, Eklund A. Lung T-helper cells expressing T-cell receptor AV2S3 associate with clinical features of pulmonary sarcoidosis. Am J Respir Crit Care Med. 2000;161(3 Pt 1):814-8. doi:10.1164/ajrccm.161.3.9906001.

19. Kotecha N, Krutzik PO, Irish JM. Web-based analysis and publication of flow cytometry experiments. In: Paul Robinson J, editor. Current protocols in cytometry/editorial board. 2010. p. Chapter 10-Unit10 7. doi:10.1002/ 0471142956.cy1017s53.

20. Kriegova E, Arakelyan A, Fillerova R, Zatloukal J, Mrazek F, Navratilova Z, et al. PSMB2 and RPL32 are suitable denominators to normalize gene expression profiles in bronchoalveolar cells. BMC Mol Biol. 2008;9:69. doi:10.1186/1471-2199-9-69.

21. Livak K. Analysis of relative gene expression data using real-time quantitative PCR and the $2-\Delta \Delta C T$ method. Methods. 2001;25(4):402-8. doi:10.1006/meth.2001.1262.

22. Becker J, Delayre-Orthez C, Frossard N, Pons F. Regulation of inflammation by PPARs: a future approach to treat lung inflammatory diseases? Fundam Clin Pharmacol. 2006;20(5):429-47. doi:10.1111/j.1472-8206.2006.00425.x.

23. Dubrac S, Schmuth M. PPAR-alpha in cutaneous inflammation. Dermato-endocrinology. 2011;3(1):23-6. doi:10.4161/derm.3.1.14615.

24. Delayreorthez C, Becker J, Auwerx J, Frossard N, Pons F. Suppression of allergen-induced airway inflammation and immune response by the peroxisome proliferator-activated receptor-alpha agonist fenofibrate. Eur J Pharmacol. 2008;581(1-2):177-84. doi:10.1016/j.ejphar.2007.11.040.

25. Klotz L, Schmidt M, Giese T, Sastre M, Knolle P, Klockgether T, et al. Proinflammatory stimulation and pioglitazone treatment regulate peroxisome proliferator-activated receptor gamma levels in peripheral blood mononuclear cells from healthy controls and multiple sclerosis patients. J Immunol. 2005;175(8):4948-55.

26. Dubuquoy L, Jansson EA, Deeb S, Rakotobe S, Karoui M, Colombel JF, et al Impaired expression of peroxisome proliferator-activated receptor gamma in ulcerative colitis. Gastroenterology. 2003;124(5):1265-76.

27. Lakshmi SP, Reddy AT, Zhang Y, Sciurba FC, Mallampalli RK, Duncan SR, et al. Down-regulated peroxisome proliferator-activated receptor gamma (PPARgamma) in lung epithelial cells promotes a PPARgamma agonist-reversible proinflammatory phenotype in chronic obstructive pulmonary disease (COPD). J Biol Chem. 2014;289(10):6383-93. doi:10.1074/jbc.M113.536805.

28. Idali F, Wiken M, Wahlstrom J, Mellstedt H, Eklund A, Rabbani H, et al. Reduced Th1 response in the lungs of HLA-DRB1*0301 patients with pulmonary sarcoidosis. Eur Respir J. 2006;27(3):451-9. doi:10.1183/ 09031936.06.00067105.

29. Dubrac S, Elentner A, Schoonjans K, Auwerx J, Schmuth M. Lack of IL-2 in PPAR-alpha-deficient mice triggers allergic contact dermatitis by affecting regulatory T cells. Eur J Immunol. 2011;41(7):1980-91. doi:10.1002/ eji.201041357

30. Guri AJ, Mohapatra SK. Horne 2nd WT, Hontecillas R. Bassaganya-Riera J The role of T cell PPAR gamma in mice with experimental inflammatory bowel disease BMC Gastroenterol. 2010;10:60. doi:10.1186/1471-230X-10-60.

31. Idali F, Wahlström J, Müller-Suur C, Eklund A, Grunewald J. Analysis of regulatory $T$ cell associated forkhead box P3 expression in the lungs of patients with sarcoidosis. Clin Exp Immunol. 2008;152(1):127-37. doi:10.1111/j.1365-2249.2008.03609.x.

32. Tondell A, Moen T, Borset M, Salvesen O, Ro AD, Sue-Chu M. Bronchoalveolar lavage fluid IFN-gamma + Th17 cells and regulatory T cells in pulmonary sarcoidosis. Mediators Inflamm. 2014;2014:438070. doi:10.1155/2014/438070.

33. Miyara M, Amoura Z, Parizot C, Badoual C, Dorgham K, Trad S, et al. The immune paradox of sarcoidosis and regulatory T cells. J Exp Med. 2006;203(2):359-70. doi:10.1084/jem.20050648.

34. Huang H, Lu Z, Jiang C, Liu J, Wang Y, Xu Z. Imbalance between Th17 and regulatory T-Cells in sarcoidosis. Int J Mol Sci. 2013;14(11):21463-73. doi:10.3390/ijms141121463. 
35. Facco M, Cabrelle A, Teramo A, Olivieri V, Gnoato M, Teolato S, et al. Sarcoidosis is a Th1/Th17 multisystem disorder. Thorax. 2011;66(2):144-50. doi:10.1136/thx.2010.140319.

36. Ostadkarampour M, Eklund A, Moller D, Glader P, Olgart Hoglund C, Linden A, et al. Higher levels of interleukin IL-17 and antigen-specific IL-17 responses in pulmonary sarcoidosis patients with Lofgren's syndrome. Clin Exp Immunol. 2014;178(2):342-52. doi:10.1111/cei.12403.

37. Cosmi L, Santarlasci V, Maggi L, Liotta F, Annunziato F. Th17 plasticity: pathophysiology and treatment of chronic inflammatory disorders. Curr Opin Pharmacol. 2014;17C:12-6. doi:10.1016/j.coph.2014.06.004.

38. Lee JW, Bajwa PJ, Carson MJ, Jeske DR, Cong Y, Elson CO, et al. Fenofibrate represses interleukin-17 and interferon-gamma expression and improves colitis in interleukin-10-deficient mice. Gastroenterology. 2007;133(1):108-23. doi:10.1053/j.gastro.2007.03.113

39. da Rocha Junior LF, Rego MJ, Cavalcanti MB, Pereira MC, Pitta MG, de Oliveira PS, et al. Synthesis of a novel thiazolidinedione and evaluation of its modulatory effect on IFN- gamma, IL-6, IL-17A, and IL-22 production in PBMCs from rheumatoid arthritis patients. BioMed research international. 2013;2013:926060. doi:10.1155/2013/926060.

40. Klotz L, Burgdorf S, Dani I, Saijo K, Flossdorf J, Hucke S, et al. The nuclear receptor PPAR gamma selectively inhibits Th17 differentiation in a T cell-intrinsic fashion and suppresses CNS autoimmunity. J Exp Med. 2009;206(10):2079-89. doi:10.1084/jem.20082771.

41. de Sousa AR, Penalva LO, Marcotte EM, Vogel C. Global signatures of protein and mRNA expression levels. Mol Biosyst. 2009;5(12):1512-26. doi:10.1039/b908315d.

42. Albu DI, Califano D, Avram D. Flow cytometry analysis of transcription factors in T lymphocytes. Methods Mol Biol. 2010;647:377-90. doi:10.1007/978-1-60761-738-9_23.

43. Kanakasabai S, Chearwae W, Walline CC, lams W, Adams SM, Bright JJ. Peroxisome proliferator-activated receptor delta agonists inhibit T helper type 1 (Th1) and Th17 responses in experimental allergic encephalomyelitis. Immunology. 2010;130(4):572-88. doi:10.1111/j.1365-2567.2010.03261.x.

44. Perona-Wright G, Mohrs K, Mohrs M. Nat Immunol. 2010;11(6):520-6. doi:10.1038/ni.1866.

45. Malur A, McCoy AJ, Arce S, Barna BP, Kavuru MS, Malur AG, et al. Deletion of PPAR gamma in alveolar macrophages is associated with a Th-1 pulmonary inflammatory response. J Immunol. 2009;182(9):5816-22. doi:B10.4049/jimmunol.0803504.

46. Paramothayan NS, Lasserson TJ, Jones PW. Corticosteroids for pulmonary sarcoidosis. Cochrane Database Syst Rev. 2005;2, CD001114. doi:10.1002/ 14651858.CD001114.pub2.

47. Paramothayan S, Lasserson TJ, Walters EH. Immunosuppressive and cytotoxic therapy for pulmonary sarcoidosis. Cochrane Database Syst Rev. 2006;3, CD003536. doi:10.1002/14651858.CD003536.pub2.

48. Lewis JD, Lichtenstein GR, Deren JJ, Sands BE, Hanauer SB, Katz JA, et al. Rosiglitazone for active ulcerative colitis: a randomized placebo-controlled trial. Gastroenterology. 2008;134(3):688-95. doi:10.1053/j.gastro.2007.12.012.

49. Spears M, Donnelly I, Jolly L, Brannigan M, Ito K, McSharry C, et al. Bronchodilatory effect of the PPAR- $\gamma$ agonist rosiglitazone in smokers with asthma. Clinical Pharmacology \& Therapeutics. 2009;86(1):49-53. doi:10.1038/clpt.2009.41

\section{Submit your next manuscript to BioMed Central and take full advantage of:}

- Convenient online submission

- Thorough peer review

- No space constraints or color figure charges

- Immediate publication on acceptance

- Inclusion in PubMed, CAS, Scopus and Google Scholar

- Research which is freely available for redistribution 